\title{
LITURGHIA NOETICĀ ŞI DEMNITATEA UMANĂ ÎNTRE DINAMICA CREAȚIEI ŞI SFINȚIREA FIRII. VIZIUNEA PATRISTICĂ ŞI ETHOSUL EUHARISTIC AL BISERICII ÎN POSTMODERNITATE
}

Lucian Colda*

\begin{abstract}
If, in 1979 Jean-François Lyotard mentioned in his work The Postmodern condition the fact that, what characterizes the Postmodern Era is, on one half, exactly the lack of "traditional" metanarratives - Illuminism, Idealism, Marxism and so on - and on the other half, the existence of a multitude of "languages", their role being solely that of endangering "the speech" itself, and thus paving the way to a new, extremely technical type of babylon, to a nihilist deconstructivist society, F. M. Dostoievski drew attention, long time before, in a rather prophetical manner, in his The legend of the Great Inquisitor from The Karamazov Brothers to a new and terrifying Tower of Babel in which humanity, deprived of Christly dignity gives away the "divine bread" in order to receive the "earthly" one, even at the price of final enslavement to the power of evil. A brief analysis of the metanarratives used to legitimate different kinds of mentalities capable of creating this new universal babylon can be traced in the context of a certain type of collective thinking, which Constantin Rădulescu-Motru defines as social psychology. A being's "hunger", be it of an ecclesial type, can only be satisfied through "the daily bread" which has this quality to offer divine fulness. This is the only modus vivendi of the Church that could make it the one that puts into place the final arrangements for the human destinity, but not a destiny deprived of its Christly perspective, of human dignity - as the one suggested by The Great Inquisitor -, but of a dignified destiny, in which the Church, both in its fullnes, as also through every single of its limbs, would confess: "It is not me who lives, but Christ is living through me" (Gal. 2, 20); and when a Christian says this words he does so only because he has, as Saint Apostle Paul mentioned, the
\end{abstract}

\footnotetext{
*Ph.D., Assistant Professor, at "1 Decembrie 1918" University of Alba Iulia (Faculty of Orthodox Theology), Romania.
} 


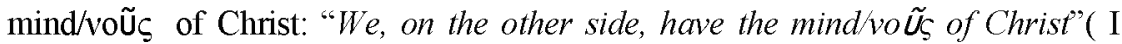
Cor. 2, 16). When Christ nurtures the Church with His body, the Church becomes itself His body. The horrendous Tower of Babel is demolished and on its ruins is build the Temple in which the deified mind of the Church officiates the perpetual Noetic Liturgy. The place of the Great Inquisitor is taken by the Great Priest, Christ, whom the Church shall follow in order to again and again receive in peace the divine bread. That is why the ontological imperative of the Church is the one of perpetually receiving the dignified nourishment, the Eucharistic nourishment in order that the Holy Communion become its daily nutriment and to guide it on its path situated somewhere between the dynamic of creation and the consecration of being. This is, in fact, the Eucharistic ethos of the Church which can be defined as a grand narrative/metanarrative of the Church deifying.

Keywords: Noetic Liturgy, (post)modernism, J.-Fr. Lyotard, Constantin Rădulescu-Motru, F.M. Dostoievski, grand narratives/metanarratives, social psychology, the Tower of Babel, daily bread/eucharistic bread, dynamic of creation, consecration of being, the Eucharistic ethos of the Holy Church.

\section{Prolegomena}

Dacă în 1979, Jean-François Lyotard remarca în lucrarea sa Condiția postmodernă, faptul că, ceea ce caracterizează epoca postmodernității este, pe de-o parte, tocmai lipsa metanarațiunilor "tradiționale" - iluminism, idealism, marxism etc. -, iar pe de alta, existența multitudinilor de „limbaje”, care nu fac altceva, decât să pună în pericol „vorbirea" însăşi, deschizând, astfel, calea spre un babilonism nou, ultratehnicizat, spre o societate deconstructivistnihilistă ${ }^{1}$, Dostoievski atrăgea atenția deja cu mult înainte, am putea spune, în chip „profetic”, asupra unui „nou şi înfricoşător Turn Babel", pe care, în lumina celor pe care le trăim şi le experimentăm noi înşine în contemporaneitate, l-am putea considera drept genul de metanarațiune deconstructivistă, care ar pune în pericol nu numai vorbirea, respectiv limbajul şi mentalitatea colectivă ca expresie a unei anume psihologii sociale, ci demnitatea umană însăşi,

${ }^{1}$ Pr. Prof. Ion Buga, Testament Gutenberg, Bucureşti, Editura Sf. GheorgheVechi, 2015, p. 148. 
incapabilă, astfel, de a mai parcurge traseul ei existențial, susținut de o anumită dinamică a creației, spre sfințirea fírii:

„Ştii Tu, oare, că peste veacuri omenirea va da glas prin gura înțelepților şi a învăţaţilor săi că nu există pe lume crimă şi, prin urmare, nu există nici păcat, ci numai flămânzi? «Dă-le mai întâi de mâncare, şi abia după aceea le poți cere să respecte virtutea!» va sta scris pe steagul celor ce se vor scula împotriva Ta, culcând templul durat de Tine. Pe ruinele templului Tău se va zidi o altă clădire, un nou şi înfricoşător Turn Babel; se va înălța piatră cu piatră, cu toate că şi el va împărtăşi soarta celui dintâi, rămânând, ca şi acela, neterminat (...) cine va da de mâncare mulțimii va apuca să-l ducă la bun sfârşit, şi noi vom fi aceia care o vom hrăni în numele Tău, amâgind-o în numele Tău. $\mathrm{O}$, în vecii vecilor, fără noi, ei nu vor ajunge să-şi astâmpere foamea! Toată înțelepciunea lumii nu va putea sa le dea pâine atâta timp cât vor rămâne liberi; dar ai să vezi că, până la urmă, ne vor aduce singuri plocon libertatea şi, depunândo la picioarele noastre, ne vor spune: «Înrobiți-ne, dar astâmpărați-ne foamea!» Abia atunci vor înţelege, în fine, că, libertatea şi faptul de a avea pâine în realitate şi cu prisosință, aşa ca să ajungă pentru toată lumea, sunt două lucruri incompatibile, fiindcă în vecii vecilor oamenii nu vor fi în stare să împartă pâinea între ei! Şi în acelaşi timp se vor convinge că niciodată nu vor putea fi liberi, fiindcă sunt slabi de înger, dedaţi la rele, bicisnici şi îndărătnici. Tu le-ai făgăduit pâinea cerească, dar iarăşi Te întreb, crezi, într-adevăr, că, poate avea acelaşi preț în ochii stirpei omeneşti, nevolnice, desfrânate şi pururea nerecunoscătoare ca pâinea reală, pământească? Dacă în numele pâinii cereşti se vor găsi câteva mii sau zeci de mii de suflete mari şi puternice care să Te urmeze, cum rămâne cu milioanele şi zecile de mii de milioane de făpturi omeneşti, incapabile să renunțe la hrana pământească pentru cea făgăduită în ceruri?"²

${ }^{2}$ Fragmentul citat face parte din ceea ce este cunoscut sub numele de Legenda Marelui Inchizitor. Noi 1-am preluat din volumul Marele Inchizitor. Dostoievski - lecturi teologice, traducere din limba rusă de Leonte Ivanov, colecția „Plural M”, Iași, Polirom, 1997, p. 16-17, care, la rândul său, îl preia din volumul F.M.Dostoievski, Frații Karamazov, traducere de Ovidiu 
După cum pertinent remarca Vasili V. Rozanov ${ }^{3}$, unul dintre interpreții consacrați ai lui Dostoievski, Legenda Marelui Inchizitor, din care am citat şi noi un fragment mai sus, poate fi considerată ca fiind ideea privitoare la orânduirea definitivă a destinelor omenirii, idee care, de altfel, va fi respinsă, totuşi, de Dostoievski, în cele din urmă, în lucrarea Însemnări din subterană, cu singura diferență că, dacă acolo, în ancadramentele unei anumite dinamici a creației se va vorbi despre o orânduire rațională, bazată pe studiul subtil şi detaliat al legilor naturii fizice şi al relațiilor sociale deosebit de complexe ale societăţii ruse contemporane lui, în Legenda Marelui Inchizitor se ilustrează întemeierea unui nou mod de existență al societății, e drept, pe baze religioase, fie ele chiar şi lipsite de libertatea şi demnitatea hristică, prin întrepătrunderea straturilor cele mai adânci ale structurii psihice umane, în care orice urmă de sfințire a firii devine imposibil de remarcat, cu atât mai mult, cu cât omenirea însăşi renunţă la demnitatea ei, în conformitate cu strigătul caracteristic unei babilonii universale: „Înrobiți-ne, dar astâmpărați-ne foamea!”.

Pornind de la aceste câteva afirmații, vom considera acest text, drept criteriu hermeneutic al ideilor pe care dorim să le exprimăm în cadrul acestei expuneri, care îşi are ca punct de plecare tocmai analiza sumară a „metanarațiunilor" de legitimare ale diverselor tipuri de mentalități capabile să creeze acea nouă babilonie universală amintită mai sus, în contextul unei anume tipologii de gândire colectivă, pe care Constantin Rădulescu-Motru o definea sub sintagma ,psihologie socială”.

Constantinescu și Isabella Dumbravă, Bucureşti, EPLU/Editura Univers, 1964.

${ }^{3}$ Despre legenda „Marele Inchizitor”, în vol. Marele Inchizitor. Dostoievskilecturi teologice ..., p. 121. 
2. Tipuri de mentalități şi metanaraţiunile de legitimare ale acestora ca paradigmă a postmodernității. Câteva reflecții asupra conceptelor de rescriere a modernității la Jean-François Lyotard şi de psihologie socială la Constantin Rădulescu-Motru

Discipol marcant al lui Titu Maiorescu, Constantin RădulescuMotru avea să se impună pe parcursul vieții sale ca filosof, psiholog, pedagog, om politic, dramaturg, director de teatru, academician şi preşedinte al Academiei Române, devenind astfel, una dintre personalităţile marcante şi fecunde ale vieții culturale româneşti din prima jumătate a secolului al XX-lea ${ }^{4}$.

La capătul celeilalte jumătăți de veac, se merită a fi reținut un alt nume: cel al lui Jean-François Lyotard, pe care deja l-am amintit. Figură a scenei intelectuale franceze, teoretician al postmodernului, acesta s-a impus, aşa după cum remarca Ioan Vultur, „printr-o uimitoare profunzime a traiectelor reflexive, prin pluralitate a viziunilor şi a formulelor discursive"

Se impune în mod legitim o întrebare: ce-i uneşte pe aceşti doi mari gânditori, sau, eventual, ce-i deosebeşte? Pentru a putea da un răspuns care, desigur, nu se doreşte nici pe departe a fi unul exhaustiv, vom recurge la analiza a două concepte aparținând acestora; este vorba de conceptul de psihologie socială şi de cel de rescriere a modernitătiii. În analiza noastră ne vom raporta, în ceea ce-l priveşte pe gânditorul român la colecția de studii editată sub titlul Psihologia poporului român şi alte studii de psihologie

${ }^{4}$ Pentru alte detalii, să se consulte articolul Constantin Rădulescu-Motru, la următoarea adresă web: http://ro.wikipedia.org/wiki/Constantin_R\%C4\%83dulescu-Motru (Standul accesării: 25.04. 2015).

I. Vultur, O versiune a postomdernității, în ,,Viaţa Românească - Revistă a Uniunii Scriitorilor", anul LXXXVII, iunie-iulie, nr. 6-7, 1992, p. 121. Pentru alte elemente bio-bibliografice legate de personalitatea intelectualului francez, poate fi consultat articolul Jean-François Lyotard, la următoarea adresă web: http://en.wikipedia.org/wiki/Jean-Fran\%C3\%A7ois_Lyotard (Standul accesării: 25.04.2015). 
socială ${ }^{6}$, iar raportat la discursul intelectualului francez, vom urmări ideile exprimate de acesta în eseul său, $A$ rescrie modernitate ${ }^{7}$.

\subsection{Jean-François Lyotard şi rescrierea modernității}

Spre deosebire de alți analişti ai fenomenelor şi paradigmelor postmodernităţii, Jean-François Lyotard consideră că, atunci când acestea sunt supuse unui proces de gândire reflexivă, trebuie avut în vedere faptul că, de fapt, avem de-a face nu cu o perioadă istorică ce ar încadra aceste fenomene şi paradigme, ci cu un anume mod de gândire ce comportă aceste specificități. Pornind de la această premisă, precum şi de la avantajul conferit de cele „două deplasări” pe care el le remarcă şi anume, una lexicală, care presupune transformarea prefixului „post” în „re”, şi alta sintactică, preocupată de aplicarea prefixului astfel modificat nu atât substantivului „modernitate" cât mai ales verbului „a scrie”, Lyotard ajunge la concluzia necesității „rescrierii modernitătii”. De ce a acesteia şi nu a postmodernității, devine pentru el clar tocmai din această schimbare a paradigmelor, schimbare sugerată de o manieră analogică, prin schimbarea impusă de cele „două deplasări” amintite mai sus. Ca urmare, dacă acest argument, care aduce cu sine nu numai o simplă schimbare de structură gramaticală sau de lexic, ci o invitație la schimbarea unui anume mod de gândire, mai mult sau mai puțin colectiv, rezultă automat că, „nici modernitatea, nici aşa-zisa <postmodernitate> nu pot fi identificate şi definite ca entități istorice clar circumscrise, în care a doua ar urma neapărat după prima"s.

Drept urmare, Lyotard deduce de aici faptul că, modernul

${ }^{6}$ Constantin Rădulescu-Motru, Psihologia poporului român şi alte studii de psihologie socială, ediție îngrijită de Alexandru Boboc, Colecția de studii și eseuri, Bucureşti, Paideia, 1998.

J.-Fr. Lyotard, A rescrie modernitatea, în ,Viaţa Românească - Revistă a Uniunii Scriitorilor", anul LXXXVII, iunie-iulie, 1992, nr. 6-7, p. 122-127, traducere de Smaranda Vultur, după originalul francez Réecrire la modernité din vol. L'inhumain. Causeries sur le temps, Paris, Edition Galilée, 1988.

8 Ibidem, p. 122. 
conține în sine de o manieră ex-plicită postmodernul, sau, altfel formulat, postmodernul este conținut de o manieră im-plicită în modern, „pentru faptul că modernitatea, temporalitatea modernă comportă în sine impulsul de a trece într-o altă stare decât ea însăşi"”.

Ținta finală a acestei schimbări de paradigme, nu este alta, decât aceea de a dobândi „un fel de stabilitate ultimă”, stabilitate vizată, pe de-o parte, de un anume gen de proiect, considerat de către Lyotard a fi mai degrabă unul „utopic”, iar pe de altă parte, de un proiect considerat a fi unul „simplu”, dar cu un puternic caracter „politic", ce se doreşte a fi „implicat în marile istorii de emancipare”. De unde concluzia cu caracter demonstrativ: „Prin însăşi constituţia sa şi fără oprire, modernitatea dă naştere postmodernității” ${ }^{10}$.

Această concluzie nu este altceva, decât răspunsul pe care Lyotard i-l dă filosofului şi sociologului german Jürgen Habermas ${ }^{11}$, cu ocazia unui dialog purtat cu acesta şi anume că, postmodernul (respectiv postmodernitatea) nu este altceva, decât o dimensiune a modernului (respectiv a modernității): „Postmodernul astfel înțeles nu este modernismul ajuns la capătul său, ci în stare născândă, iar această stare este recurentă"12.

În argumentarea sa, Lyotard apelează şi la alte surse, precum S. Freud, care analizează un anume gen de comportament şi mentalitate ilustrat de figura legendarului Oedip. Studiul freudian, pe care Lyotard îl consideră a fi unul „memorabil”, distinge trei paliere de acțiune a acestui tip de mentalitate, paliere marcate sugestiv de ceea ce se doreşte a fi „repetiția, rememorarea şi perlaborarea”. „Repetiția”, înțeleasă drept „produsul nevrozei sau al psihozei”,

9 Ibidem.

${ }^{10}$ Ibidem .

${ }^{11}$ Pentru persoana și opera filosofului și sociologului german, să se consulte articolul Jürgen Habermas, la următoarea adresă web: http://en.wikipedia.org/wiki/J\%C3\%BCrgen_Habermas (Standul accesării: 25.04.2015).

12 J.-Fr. Lyotard, Răspuns la intrebarea: „Ce este postmodernismul ?", prezentare si traducere de Mihai Dinu Gheorghiu, în „Caiete critice”, 1986, nr. 1-2, p. 173-179, apud I. Vultur, O versiune a postomdernitătii, p. 121. 
rezultă din ceea ce poate fi numit generic „dispozitiv”, permițând dorinței inconştiente să devină realitate palpabilă, existența subiectului fiind organizată astfel ca o „dramă”. Viața subiectului primeşte în felul acesta conturul unul „destin”, el devenind, astfel, captivul unui anume gen de ,predestinare”. Ca urmare, viitorul este înscris în „trecutul deja spus”, iar subiectul „repetă fatum-ul, chiar dacă e ignorant de acest lucru". Subiectul - în cazul de faţă regele Oedip - încearcă să devină conştient, pentru a descoperi „motivul” sau cauza tulburării de care suferă pe parcursul vieții sale, sau cum formulează Lyotard, Oedip „vrea să adune la un loc temporalitatea nestăpânită, dezmembrată" ${ }^{\prime \prime}$.

Oedip purcede ca urmare a acestei tehnici introspective de cercetare, la a identifica ceea ce este "cauza răului” sau pricina suferinței sale, angajându-se la un alt nivel al cunoaşterii, oferit lui de cel de-al doilea palier amintit mai sus, anume de „rememorare”. Din această perspectivă, „a rescrie modernitatea - spune Lyotard - se înțelege adesea în acest sens, cel al rememorării, ca şi când ar fi vorba de a repera şi a identifica o serie de crime, păcate, calamități generate de dispozitivul modernităţii (...)"14.

Acest gen de „rescriere” poate fi însă unul păgubos, unul care amăgeşte. Amăgirea aceasta rezultă tocmai din faptul că, „ancheta întreprinsă asupra originilor destinului face ea însăşi parte din acest destin"15. Dacă, însă, vom încerca „a rescrie modernitatea" echivalând acest proces cu „a căuta, a desemna şi a numi faptele ascunse pe care le imaginăm la originea răului de care suferim, (...) nu vom face altceva decât să perpetuăm crima, să o comitem, în loc să-i punem capăt" ${ }^{\prime \prime}$. Altfel spus, nu vom reuşi decât să scriem încă o dată modernitatea, căci „a scrie înseamnă a rescrie”. Modernitatea se află, astfel, într-o permanentă „re-scriere”.

$\mathrm{Ca}$ exemplu în sprijinul acestei aserțiuni, Lyotard aduce mărturie exemplul marxismului, care a crezut ca va reuşi prin

\footnotetext{
${ }^{13}$ Idem, A rescrie modernitatea, p. 123.

${ }^{14}$ Ibidem, p. 124.

${ }^{15}$ Ibidem.

${ }^{16}$ Ibidem.
} 
„dezalienarea" forței de muncă, a maselor, aşadar, să atingă un nivel ridicat de emancipare şi conştientizare, eliminând exploatarea omului de către om. Rezultatul a fost însă contrar aşteptărilor, ajungându-se la o nouă alienare, similară celei combătute, „cu modificări abia perceptibile".

La fel, aşa după cum remarca Heidegger, la care Lyotard face apel, filosofia nietzscheiană repetă, împotriva ei însăşi, aceeaşi eroare, atunci când respinge existența unui „Grund”, adică a unui „principiu originar”, aşa cum se regăseşte el deja la Platon sub forma ideii de „Bine” sau la Leibniz, ca „principiu al rațiunii suficiente”. Ca urmare, Nietzsche reiterează „procesul metafizic” concretizat într-o „metafizică a voinței”, metafizică ce este, în esența ei, „conținută de toate sistemele filosofice ale Occidentului modern". Aceasta ar duce la o reflecție din partea noastră „asupra unei rescrieri care s-ar sustrage, atât cât e posibil, repetării a ceea ce ea re-scrie". Mai mult, arată Lyotard, „s-ar putea ca resortul procesului de rememorare să fie voința însăşi. Este ceea ce Freud intuieşte atunci când disociază perlaborarea (Durcharbeitung) de rememorare, (Erinnerung) ${ }^{17}$.

Mergând mai departe cu analiza sa, Lyotard arată că, de fapt, „rememorându-ne, vrem ceva mai mult". Acest fel de a vrea, echivalează pentru el cu luarea în posesie a trecutului, cu analiza acestuia şi cu identificarea pe baza acestei analize a crimei inițiale, făcându-o să se manifeste ca atare, ca şi când aceasta ar duce la detaşarea ei de contextul afectiv în care ea a avut loc, aşa precum încerca, de fapt, regele Oedip. Uităm, însă, spune Lyotard că, ,însăşi voința de a identifica originea răului se naşte din dorință. Căci ține de esența dorinței să dorească a se depăşi pe sine, pentru că dorința e insuportabilă’"18. Încercarea de amintire nu este, ca atare, altceva, decât - şi aceasta în mod paradoxal - un mijloc de a uita. Acesta este pentru Lyotard, echivalentul unei mentalități reflectate de un anume mod de a „redacta" istoria; din nefericire, acest mod de redactare, duce, de fapt, la „reducerea” ei. Este, la urma urmei, un proces

${ }^{17}$ Ibidem.

${ }^{18}$ Ibidem, p. 125. 
înscris în cadrele delimitate de latinescul redigere şi de englezescul putting down; cu alte cuvinte, avem de-a face, cu a „redacta” şi a „reprima”, atunci când este vorba de o „rescriere” în această manieră a istoriei. Şi aceasta este, de fapt, rezultatul unei anumite mentalităţi. Este o mentalitate care, pe lângă cadrele trasate de redigere şi putting down, reflectă şi o altă dimensiune, adiacentă celor două: writing down, care sugerează simultan „înscriere sau înregistrare, dar şi discredit" $"$.

Această ultimă dimensiune se regăseşte şi la Nietsche, atunci când, în opera sa Considerații inactuale, analizează „,capcanele ce pândesc cercetarea istorică". Chiar şi Freud a renunţat, în cele din urmă, la ipoteza sa asupra originii nevrozelor, trecând la ceea ce el formula ca fiind „scena primitivă”, adică scena de seducere a copilului de către adult. Astfel, el avansează o altă latură a psihanalizei şi anume, cea a finalităţii ei, sugerându-se prin aceasta faptul că, ,procesul curativ ar trebui să fie indeterminat" ${ }^{\prime 20}$.

Lyotard atrage atenția asupra faptului că, Freud a pus accent pe ceea ce se numeşte ,regulă a atenţiei egal distribuite”, regulă care trebuie adoptată de către analist vis-à-vis de pacientul său. Ca atare, în conformitate $\mathrm{cu}$ această regulă, trebuie suspendată judecata, nefiind permisă nici o prejudecată, trebuie primit tot ceea ce se comunică şi trebuie acordată atenție egală la tot ce survine şi mai ales cum survine. Acestei reguli trebuie, însă, să se supună şi pacientul, nu numai analistul. Acest mod de operare duce la situația de a fi „pacient” într-un sens nou şi anume, nu în acela de a îndura pasiv şi repetitiv aceeaşi „dramă”, ci în acela de a-şi exersa propria „posibilitate” 21 .

Ajuns în acest punct al analizei sale, Lyotard explică legătura dintre această practică ce reflectă un anume tip de mentalitate şi „rescrierea modernității”, acțiune care presupune un alt tip de mentalitate. El spune:

\footnotetext{
${ }^{19}$ Ibidem.

${ }^{20}$ Ibidem.

${ }^{21}$ Ibidem.
} 
„Vă amintesc că singurul fir conducător de care dispunem în procesul de perlaborare constă în sentiment, mai degrabă, în ascultarea sentimentului. Survine un fragment de frază, un început de informație, un cuvânt. Ele sunt legate pe loc într-o altă <unitate>. Fără raționamente, fără argumente, fără mediere. Procedând astfel, te apropii, puțin câte puțin, de o scenă, scena a ceva. O descrii. Ignori ce este, ce reprezintă. Eşti sigur doar de faptul că se raportează la ceva trecut, deopotrivă la trecutul cel mai îndepărtat şi cel mai apropiat, deopotrivă la trecutul tău şi al celorlalţi. Timpul pierdut nu e reprezentat ca într-un tablou, el nu este nici măcar prezentat. El este ceea ce ne prezintă elementele tabloului, ale unui tablou imposibil. A rescrie înseamnă a le înregistra. Este clar că această rescriere nu furnizează nici o cunoaştere a trecutului. ${ }^{22}$ "

Din această perspectivă, analiza nu mai este o problemă de cunoaştere, ci este o „tehnică”, una de artă, ceea ce presupune, din nou, un alt tip de mentalitate. Această „tehnică” se înscrie - acest lucru remarcându-1 şi Freud - într-un proces de emancipare, devenind un element constitutiv al acesteia. Retorica inconştientului este, astfel, reconstruită, iar sensul „rescrierii” trebuie înțeles ca atare, din această perspectivă.

Urmând lui Kant, care apelează la imaginea unei flăcări insesizabile în focul din vatră şi la imaginea unui desen realizat de izvoarele unui pârâu, Lyotard conştientizează că, tipul acesta de abordare al „rescrierii” este legat inevitabil de „problema timpului”, pe care o punea şi el la începutul analizei sale. Ca atare, el remarcă: „Receptarea estetică a formelor nu este posibilă decât dacă renunţăm la orice pretenție de a stăpâni timpul printr-o sinteză conceptuală. ${ }^{23}$, $\mathrm{Ca}$ urmare a acestui fapt, este necesară, spune Lyotard, bazându-se şi pe analizele lui Theodor Adorno, dar mai ales pe cele ale lui Ernst Bloch, rescrierea modernitătiii. $\mathrm{Nu}$ trebuie însă uitat faptul că, „modernitatea este, de altfel, propria sa rescriere" ${ }^{24}$.

\footnotetext{
${ }^{22}$ Ibidem.

${ }^{23}$ Ibidem, p. 126.

${ }^{24}$ Ibidem.
} 
Rescrierea, înțeleasă ca fiind relaționată cu noțiunea de „estetică a frumosului”, ține însă mai mult, după cum afirmă Lyotard, de problematica sublimului. Acest tip de „rescriere” nu are, în opinia lui Lyotard, „nici o legătură cu ceea ce este numit postmodernitate sau postmodernism pe piața ideologiilor contemporane" 25 .

O ultimă observatie pe care o face Lyotard la finalul eseului său, este aceea că, un anume fel de „re-scriere” - termen desemnat în jargonul jurnalistic prin „re-writing” - îl constituie noile tehnologii folosite în ,producerea, difuzarea distribuirea (sic!) şi consumarea bunurilor culturale într-o industrie". Este, la urma urmei, o răsturnare a mentalităților, a paradigmelor şi a modalităților de gândire, fenomen produs odată cu conferirea unei importanțe capitale conceptului de „bit”, de unitate informațională, ca semn nu al modernității, ci al postmodernității. De aceea, întrebarea: ce poate, oare, conserva utilizarea noilor tehnologii folosite în cadrul acestui proces de „re-scriere”? Lyotard se mulțumeşte să răspundă la această întrebare formulând următoarea aserțiune: „a rescrie modernitatea înseamnă a rezista scrierii acestei presupuse postmodernităţi” ${ }^{\prime 26}$.

\subsection{Constantin Rădulescu-Motru şi psihologia socială}

Aşa după cum remarca Alexandru Boboc, sub a cărui coordonare a fost editat volumul Psihologia poporului român şi alte studii de psihologie socială, Constantin Rădulescu-Motru, ale cărui eseuri privitoare la diverse aspecte ale psihologiei poporului român şi la diferitele tipuri de mentalitate regăsite în sânul acestuia au fost publicate în volumul amintit, ,a luat atitudine prin scrierile sale față de problemele epocii, a promovat iniţiativa şi a grupat energiile creatoare în jurul unor veritabile programe de cercetare şi dezvoltare ce vizau afirmarea identității spiritualității româneşti şi modernizarea

${ }^{25}$ Ibidem, p. 127.

${ }^{26}$ Ibidem. 
ei în contextul culturii europene"27.

Preocupările marelui filosof român privitoare la afirmarea culturii române moderne acoperă aproximativ o jumătate de secol, crezul său fiind cel al unei vieți închinate adevărului şi binelui ${ }^{28}$. Studiile cuprinse în volumul asupra căruia vom stărui pe scurt şi noi şi care au fost, de altfel, publicate în revistele vremii, sunt în esenţă eseuri sau analize psiho-sociologice, reliefând, pe de-o parte preocuparea filosofului român amintit pentru cunoaşterea specificului spiritualității poporului nostru şi al culturii acestuia, iar pe de altă parte, dorința afirmării personalităţii acestui popor în contextul istoriei universale.

La baza întregii opere aparținând lui Constantin RădulescuMotru stă, de fapt, un concept pe care el însuşi l-a creat şi care a devenit unul dintre reperele importante în cadrul cercetării psihosociologice româneşti: este vorba de personalismul energetic ${ }^{29}$ şi întregirea lui în teoria vocației. Din această perspectivă, psihologia persoanei şi concepția asupra personalității sunt ilustrate în ceea ce Constantin Rădulescu-Motru identifica a fi elementele de bază în psihologia popoului român şi al civilizației române moderne ${ }^{30}$.

Analizând temele propuse de autor în volumul amintit, observăm că prin analiza unor diferite tipuri de psihologie, precum cel al industriaşului ${ }^{31}$, al martorului ${ }^{32}$, al ciocoismului $^{33}$ sau al

${ }^{27}$ Al. Boboc, Constantin Rădulescu-Motru în gândirea contemporană. Postfaț̆ la vol. Constantin Rădulescu-Motru, Psihologia poporului român şi alte studii de psihologie socială, p.182.

${ }^{28}$ Notă introductivă la vol. Constantin Rădulescu-Motru, Psihologia poporului român şi alte studii de psihologie socială, p. 9.

${ }^{29}$ Vezi pentru aceasta: Constantin Rădulescu-Motru, Personalismul energetic, București, Casa Şcoalelor, 1927.

${ }^{30}$ Notă introductivă la vol. Constantin Rădulescu-Motru, Psihologia poporului român..., $\mathrm{p}, 8$.

${ }^{31}$ Constantin Rădulescu-Motru, Psihologia industriaşului, în vol. Constantin Rădulescu-Motru, Psihologia poporului român..., pp. 49-60.

32 Idem, Psihologia martorului, în vol. Constantin Rădulescu-Motru, Psihologia poporului român..., pp. 61-92. 
revoluţionarului ${ }^{34}$ ori al „sufletului” poporului român în ansamblul său ${ }^{35}$, sunt evidenţiate tot atâtea tipuri de gândire şi mentalitate, pe care Constantin Rădulescu-Motru le integrează în ceea ce ce ar putea fi definit drept „psihologie socială”, adică într-un model de mentalitate şi de gândire care poartă nu numai amprenta individuaţiunii, dacă ne-am putea exprima astfel, ci şi pe aceea, sau poate mai ales, pe cea a unui soi de comunitarism social.

Suntem înclinați la a face această afirmație pornind de la diversele tipuri de mentalitate amintite mai sus şi analizate de marele filosof român, mentalităţi care se regăsesc, sub o formă sau alta, nu numai în cadrul diverselor pături sau stratificări sociale, ci şi la nivelul colectiv, definit de ceea ce este „sufletul" poporului român. De bună seamă, vorbind de un "suflet" al poporului român, Constantin Rădulescu-Motru va fi avut în vedere postularea unui „organism” psiho-socio-cultural, numit de către el generic „neamul nostru”, organism căruia îi sunt atribuite „calităţi bune şi defecte"

Dacă fiecare popor are parte de o vocație cerută de instinctul de conservare al poporului respectiv, ea nu poate lipsi, în opinia marelui filosof român, nici din cadrul poporului nostru, căci ea „,se arată atunci când ea este cerută de instinctul de conservare a (sic!) unui popor; ea este o manifestare a energiei poporului întreg... este o canalizare a energiei poporului, şi, prin canalizare, ea este, în acelaşi timp, o valorificare" 37 .

33 Idem, Psihologia ciocoismului, în vol. Constantin Rădulescu-Motru, Psihologia poporului român..., pp. 93-106.

${ }^{34}$ Idem, Psihologia revoluţionarului, în vol. Constantin Rădulescu-Motru, Psihologia poporului român..., pp. 107-138.

${ }^{35}$ Idem, Psihologia poporului roman și Sufletul neamului nostru. Calități bune şi defecte, în vol. Constantin Rădulescu-Motru, Psihologia poporului român..., pp. 11-32 și pp. 33-48.

${ }^{36}$ Ibidem.

37 Idem, Vocația. Factor hotărâtor în cultura popoarelor, 1935, apud Notă introductivă la vol. Constantin Rădulescu-Motru, Psihologia poporului român..., p. 8. Studiul a fost reeditat şi în anul 1984, la București, în vol. Personalismul energetic şi alte scrieri, precum și în anul 2005 la editura Albatros, în colecția „Ethnos”. 
Scopul țintit de către Constantin Rădulescu-Motru în toate aceste scrieri ale sale, nu a fost altul, decât formarea unei conştiințe critice necesare poporului român, care să dezvăluie lumii şi culturii moderne spiritul de discernământ al acestuia, bazat pe obiectivitate, realism şi optimism. În aceste cadre trebuie înţeles şi conceptul de „psihologie socială” formulat de către Constantin Rădulescu-Motru, care vedea în ea modalitatea prin care pot fi determinate şi apoi explicitate însuşirile sufleteşti ale unei populații, acestea fiind condiționate de trei factori principali: de fondul biologic ereditar al populației respective, de mediul geografic în care aceasta îşi desfăşoară existența şi de caracterele instituționale dobândite pe parcursul evoluției istorice a populației respective ${ }^{38}$.

Desigur, aceşti trei factori nu joacă acelaşi rol sau nu pot fi socotiți ca fiind egali în procesul de determinare al unui popor. Mai mult, aşa cum remarca marele filosof român, „nu toate populațiile sunt capabile de cultură națională”, căci „spiritualitatea nu este un produs al timpului" ${ }^{39}$. Introducerea elementului spiritualității este esențial pentru Constantin Rădulescu-Motru, deoarece, „psihologia socială, care are drept obiect studiul vieții sufleteşti a organismelor sociale, se găseşte, după populaţie, înaintea unei vieți sufleteşti deosebite. Când studiază sufletul unei populații lipsite de o armură spirituală, obiectul ei se reduce la studierea manifestărilor sufleteşti simple, pe jumătate biologice”40. Dacă, însă, „psihologia socială” va recurge la studiul unor populaţii cu un trecut istoric bine definit şi cu instituții spirituale bine înrădăcinate, atunci obiectul său este total schimbat, deoarece sufletele unor astfel de populații conţin în ele „realități suprabiologice”"41.

Considerăm că sunt suficiente aceste câteva repere din gândirea lui Constantin Rădulescu-Motru privitoare la conceptul de „psihologie socială”, pentru a reliefa modalitatea prin care el

${ }^{38}$ Idem, Psihologia poporului român în vol. Constantin Rădulescu-Motru, Psihologia poporului român..., p. 11.

${ }^{39}$ Ibidem, p. 12.

${ }^{40}$ Ibidem, p.13.

${ }^{41}$ Ibidem. 
analizează diverse tipuri de comportament şi de mentalitate, aşa cum sunt ele prezentate în volumul amintit mai sus. Este, de fapt, inițierea unui mod de gândire filosofic puternic ancorat nu numai în realitățile psihologice, culturale şi sociale ale poporului român, ci şi în ceea ce determină aceste realități, în ceea ce am putea numi o ,metarealitate” sau o „realitate metafizică”. $\mathrm{Cu}$ alte cuvinte, avem de-a face cu parcurgerea unui traseu descris şi de către Hegel, care remarca faptul că, ,straniul spectacol al unui popor civilizat lipsit de metafizică” se aseamănă cu un ,templu, de altfel bogat împodobit, dar lipsit de sanctuar"

\subsection{Reflecții concluzive}

La finalul acestor câteva considerații, înainte de a parcurge mai departe traseul propus pentru acest studiu, vom încerca să vedem ce anume ar putea avea în comun cei doi gânditori analizați succint de noi mai sus, sau ce îi deosebeşte.

Prima constatare pe care dorim s-o facem, este aceea că, din perspectiva unei analize analitice conceptual-descriptive, cei doi autori analizați au în comun mai puține lucruri decât cele care îi deosebesc.

În al doilea rând, dacă ne raportăm numai la cele comune, leam putea identifica pe acestea ca fiind preocuparea de a cerceta şi reliefa anumite tipuri de mentalități, cercetare ce s-ar putea înscrie, în opinia noastră, într-un proces de „rescriere”, dacă ar fi să folosim terminologia propusă de J.-Fr. Lyotard. Atât el, cât şi Constantin Rădulescu-Motru ,,rescriu”, fiecare în stilul şi-n felul său propriu, un anumit gen de realitate, corespunzător unui anumit tip de mentalitate. Aceste gen, sau aceste genuri se doresc a fi legitimate de anumite genuri de „metanarațiuni”. Lyotard vede mai degrabă un declin al acestor metanarațiuni, instaurându-se un „clivaj între narațiunile din

${ }^{42}$ G.W.F. Hegel, Ştiința logicii, București, Editura Academiei, 1996, p. 7-8, apud Al. Boboc, Constantin Rădulescu-Motru în gândirea contemporană. Postfaţă la vol. Constantin Rădulescu-Motru, Psihologia poporului român..., p.182. 
societăţile tradiţionale şi cunoaştere"433.

Pentru Constantin Rădulescu-Motru ruptura aceasta pare a nu fi pe deplin realizată, ea fiind salvată de progresul spiritual al popoarelor, de dimensiunea metafizică a spiritualității, de ceea ce am numit noi ,meta-realitate". Aceasta este una centrată pe dimensiunea socială a etnicului, de unde şi nevoia de a vorbi despre o psihologie socială. Etnicul, fără a fi absolutizat, este perceput de el ca spațiu de comunicare în care se revelează un ideal mai înalt, unul în care se înscrie şi poporul nostru, cu calităţile lui bune, dar şi cu defectele sale.

Viziunea aceasta, am putea spune, este diferită radical de cea a lui Lyotard, care, neascunzând în analizele sale sentimentul de respingere față de tot ceea ce poate a fi încadrat într-un sistem tradițional sau marcat de o amprentă spirituală, renunță la demersul teoretic obişnuit, inițiind un demers quasi-nou, în care granițele dintre ştiință şi creație şi dintre activitatea teoretică şi cea artistică sunt eliminate, justificându-şi, astfel, teoria declinului absolut şi ireversibil al metanaratiunilor prin care diversele tipuri de mentalități s-ar putea legitima. El propune o analiză care ține mai mult nu de elaborările metafizicii, aşa cum se regăsesc ele la Constantin Rădulescu-Motru, ci de o investigare subtilă şi amănunțită a figuralului, în care un loc de seamă revine filosofiei antice, semiologiei şi psihanalizei freudiene, bazată pe introspecția abisală a subconştientului care, astfel, devine modalitate de „rescriere" a unui anume tip de mentalitate sau chiar a modernității, postomdernitătiii fiindu-i refuzat statutul de perioadă istorică şi fiindu-i atribuit numai unul de modalitate de gândire ${ }^{44}$.

Încheind, reluăm o aserțiune a lui Ion Vultur, care remarcă faptul că, tezelor lui Lyotard aplicate asupra postmodernității „li se pot opune şi li s-au opus alte concepții" ${ }^{45}$. În opinia noastră, acestor teze, mai degrabă pesimiste şi lipsite de dimensiunea metafizică a

\footnotetext{
${ }^{43}$ I. Vultur, $O$ versiune a postomdernității..., p.121.

${ }^{44}$ Ibidem.

${ }^{45}$ Ibidem, p. 121-122.
} 
spiritualitătii, teze elaborate la sfârşitul secolului trecut, li se pot opune cele ale lui Constantin Rădulescu-Motru, marcate de optimismul regenerării şi renaşterii culturale şi sociale, aşa cum sunt ele ilustrate în psihologia socială a poporului român. Iar dacă Lyotard considera că, rescrierea postmodernitătiii ar trebui evitată, limitându-ne doar la rescrierea modernității, găsim de cuviință să afirmăm că, postmodernitatea poate fi rescrisă, iar această rescriere este înlesnită, poate, tocmai de ceea ce Constantin Rădulescu-Motru definea a fi psihologie socială.

Oricum, atât într-un caz, cât şi-n celălalt, este vorba, la urma urmei, de o anumită cunoaştere, capabilă să discearnă între ceea ce se lasă a fi doar pur şi simplu numai repetat şi ceea ce se doreşte a fi, efectiv, rescris, într-o dinamică a creației ce surprinde omul în drumul său spre sfințirea propriei lui firi.

\section{3. „O, pune-mă pe inimă pecete!” (Cântarea Cântărilor 8, 6). De la inima pecetluită, la mintea îndumnezeită}

Atunci când redacta celebrele Questiones Disputatae, afirmând drept sententia certa ceea ce, de fapt, ilustra caracteristica unei societăti umane ,flămânde" de cunoaştere, Sf. Toma d'Aquino stipula fără echivoc, în celebrul său tratat Quaestiones disputatae de veritate $^{46}$, principiul axiomatic major al scolasticii medievale: „Nihil est in intelectu, quod non prius fuerit in sensu/Nimic nu poate fi perceput de intelect (minte), dacă mai întâi nu a trecut prin simțuri”.

${ }^{46}$ q. 2, art. 3, arg. 19. Fragmentul citat poate fi consultat la următoarea adresă web:

http://www.hispanoteca.eu/Lexikon\%20der\%20Linguistik/e/EMPIRISMUS \%20\%20\%20Empirismo.htm (Standul accesării: 25.04.2015). Axioma aceasta avea să devină, mai apoi, principiul de bază al sensualismului filosofic reprezentat de John Locke (1632-1704) și avea să fie completat de către Gottfried Wilhelm Leibniz (1646-1716) sub forma „Nihil est in intellectu, quod non prius fuerit in sensu nisi intellectus ipse/Nimic nu poate fi perceput de intelect (minte) dacă mai întâi nu a trecut prin simţuri, mai puțin intelectul însuşi”. 
Plecând de la acest principiu axiomatic tomist, ne întrebăm pe bună dreptate, în ce măsură, pecetluirea inimii corespunde unei lucrări, a cărei percepere să nu rămână doar la simpla receptare sensualistă - aserțiunea tomistă constituind mai târziu bazele filosofiei sensualiste -, ci să treacă dincolo de aceasta, adică prin filtrul intelectului, dar nu oricărui intelect, ci al unuia străfulgerat de lumina îndumnezeitoare a lui Hristos, a unui intelect pogorât în însuşi adâncul tainic al inimii pecetluite de Hristos, care să ilustreze demnitatea persoanei umane, percepută, aşa cum spun Sf. Părinţi, drept fiinţa situată între dinamica creaţiei şi sfinţirea firii acesteia. $\mathrm{Ne}$-am putut da seama, desigur, că, cel care pecetluieşte nu este altul decât Hristos, iar inima pe care El o imprimă cu sigiliul Său, nu este alta decât inima Bisericii Sale, prin Biserică înțelegând în cel mai profund sens patristic, creația întreagă.

Spre deosebire de Origen, după care creația rațională primordială este „,imobilă”, „statică”, găsindu-şi împlinirea şi logicitatea în contemplarea ființei dumnezeieşti şi nu în "dinamism" sau în „mişcare”, care nu ar fi altceva decât o formă de revoltă sau de rebeliune contra lui Dumnezeu, Părinții Bisericii au văzut şi înțeles „mişcarea” sau „dinamismul” făpturilor tocmai ca o consecință firească şi necesară a caracterului lor creatural, aflat în drum spre comuniunea şi unirea cu Dumnezeu. În sensul acesta, Sf. Maxim Mărturisitorul vorbeşte $^{47}$ despre sistemul existenţial creat de

${ }^{47}$ Răspunsuri către Talasie 60, în Filocalia sfintelor nevoințe ale desăvârşirii sau culegere din scrierile Sfintilor Părinți care artă cum se poate omul curăti, lumina şi desăvârş̧i, vol. 3, traducere, introducere şi note de Preotul Profesor Dr. Dumitru Stăniloae, Ediția a III-a, Seria „Scrieri - Traduceri - 12 de Pr. Prof. Dr. Dumitru Stăniloae" București, EIBMBOR, 2009, pp. 371-378 (Ediția a II-a, București, Editura Harisma, 1994, p. 330-335): „Prin taina lui Hristos cuvântul Scripturii a numit pe Hristos însuşi. Aceasta o mărturisește limpede marele Apostol, spunând: <Taina cea ascunsă de neamuri, s-a descoperit acum>, de unde se vede că după el taina lui Hristos este tot una cu Hristos. Iar această taină este, desigur, unirea negrăită și neînțeleasă a dumnezeirii și omenității într-un singur ipostas (...) Căci se cădea ca Făcătorul a toate, ca făcându-se prin fire, potrivit iconomiei, ceea ce nu era, să se păstreze pe Sine neschimbat, atât ca ceea ce era după fire, cât și ca ceea ce a 
Dumnezeu şi aflat într-o dinamică ce duce spre El. Raţiunea sau logosul fiecărei făpturi constă tocmai în aceea de a se afla într-o dinamică existențială, de a fi activ din punct de vedere existențial ${ }^{48}$. Sf. Justin Martirul şi Filosoful vorbise deja în veacul al II-lea despre

devenit prin fire potrivit iconomiei. Fiindcă nu se poate cugeta la Dumnezeu vreo schimbare, precum nu se poate cugeta peste tot vreo mișcare, care singură face cu putință schimbarea la cele ce se mișcă. Aceasta este taina cea mare şi ascunsă. Aceasta este ținta fericită (sfârșitul) pentru care s-au întemeiat toate. Acesta este scopul dumnezeiesc, gândit mai înainte de începutul lucrurilor, pe care definindu-1 spunem că este ținta finală mai înainte gândită, pentru care sunt toate, iar ea pentru nici una. Spre această țintă finală privind, Dumnezeu a adus la existență ființele lucrurilor. Acesta este cu adevărat sfârşitul Providenței şi al celor providențiale, când se vor readuna în Dumnezeu cele făcute de El (...) încă înainte de veacuri a fost cugetată şi rânduită unirea hotarului (definitului) şi a nehotărniciei (indefinitului), a măsurii şi a lipsei de măsură, a marginii şi a nemărginirii, a Creatorului şi a creaturii, a stabilităţii și a mișcării. Iar această taină s-a înfăptuit în Hristos, care s-a arătat în cele din urmă dintre timpuri, aducând prin ea împlinirea hotărârii de mai înainte a lui Dumnezeu. Aceasta, pentru ca cele ce se mişcă după fire să găsească odihna în jurul Aceluia care este după ființă cu totul nemişcat, din mișcarea lor față de ele însele și una față de alta; de asemenea ca să primească prin experiență cunoștința trăită a Aceluia în care s-a învrednicit să se odihnească, cunoștință care le oferă posesiunea fericită, neschimbată și constantă a Celui cunoscut de ele (..) Unii spun că Hristos a fost cunoscut mai înainte de întemeierea lumii, de către aceia cărora li s-a arătat mai apoi în timpurile de pe urmă, întrucât şi ei au existat înainte de întemeierea lumii, împreună cu Hristos cel cunoscut de mai înainte. Dar noi nu primim această învăţătură, fiindcă este cu totul străină de adevăr, ca una ce face ființa celor raționale coeternă cu Dumnezeu. Căci nu e cu putință sâ fie cineva cu Hristos precum este El şi apoi să nu maifie cu El, daca în el ajung veacurile la capătul lor și în El se opresc cele ce se află în mişcare. Fiindcă în El nici una dintre făpturi nu mai este supusă schimbării".

${ }^{48}$ Idem, Ambigua. Tîlcuiri ale unor locuri cu multe şi adînci intelesuri din sfinții Dionisie Areopagitul şi Grigorie Teologul, traducere din grecește, introducere şi note de Pr. Prof. Dumitru Stăniloae, în colecția „Părinţi și Scriitori Bisericești”, vol. 80, București, EIBMBOR, 1983, p. 58: „Așadar vom mărturisi, împreună cu firea, și mișcarea, fără de care nu este nici fire, cunoscând că altceva este rațiunea existenței şi altceva modul existenței, prima indicând firea, al doilea, iconomia." 


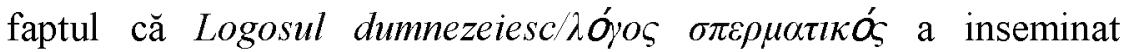
întreaga creație cu hoyol-i sau rațiunile existențiale care o susțin în drumul ei spre Dumnezeu ${ }^{49}$. Identitatea această dinamică a creației, deci a Bisericii, este reflectată, aşadar, tocmai în atingerea țelului pentru care a fost adusă la existență, adică pentru comuniunea cu

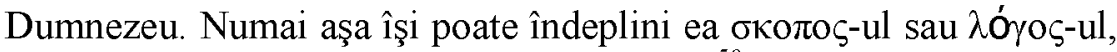
rațiunea existențială pentru care a fost creată ${ }^{50}$.

Părinții Bisericii nu au căzut, însă, în eroarea susținerii nimicirii lumii şi a veşnicei întoarceri sau a ciclicității ei, tocmai că pentru ei, în actul lor de theologhisire a prevalat mereu independența față de izvoarele nescripturistice. Bunăoară, Sf. Vasile cel Mare rămîne fidel ideii biblice de transcendență şi libertate dumnezeiască absolută în actul creației. Astfel, asemenea Sf. Atanasie cel Mare, care respinge concepția elenist-origenistă a unei creații în timp şi distrugeri ciclice a acesteia, Sf Vasile susține ${ }^{51}$ realitatea unei mişcări create, respectiv a unui dinamism creat în făpturi. Aoyofíi care susțin creația nu sunt considerate a fi, însă, precum în concepția stoică,

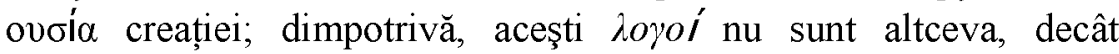

49 Arhid. Prof. Dr. Constantin Voicu, Patrologie, vol. I, Bucureşti, Editura Basilica a Patriarhiei Române, 2009 p. 144. A se vedea şi Berthold Altaner, Patrologie, Freiburg im Breisgau, Herder \& CO. G.M.B.H. Verlagsbuchhandlung, 1938, p. 65.

${ }^{50}$ John Meyendorff, Teologia Bizantină. Teme istorice şi tendințe doctrinare, traducere din limba engleză de Preot conf. dr. Alexandru I. Stan, seria „Teologi ortodocşi străini”, Bucureşti, EIBMBOR, 1996, p. 178.

${ }^{51}$ Omilia a $V$-a, în vol. Omilii la Hexaemeron, traducere şi note de Pr. Dumitru

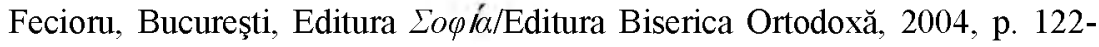
$123:,<$ Să răsară pământul>. Această mică porunca (sic!) s-a prefăcut îndată într-o puternică lege a naturii și într-o rațiune măiastră. Porunca aceta a săvârşit miile şi miile de însușiri ale plantelor şi ale arborilor, mai iute decât un gând de-al nostru. Pământul are în el şi acum această poruncă şi-1 silește, în fiecare anotimp al anului, să dea la iveală puterea pe care o are, pentru răsrirea plantelor, semințelor şi arborilor. După cum titirezul, după ce a fost fixat în vârf, se învârtește în continuare de la cea dintâi lovitură ce i se dă, tot aşa şi natura, luând început de la cea dintâi poruncă, se continuă în tot timpul care urmează, până ce se va ajunge la sfârșitul obștesc al universului". 
rațiunile existențiale prin care pronia divină a adus creația la existență, menținându-o şi proniindu-o, însă nu cu prețul dinamismului creat al lumii, ci prin propria ei voință şi bunăvoință ${ }^{52}$. Iar dacă ar fi să formulăm într-un alt fel, am putea spune că aceşti hoyo'́sunt „limbajul” creației, modul ei de a „comunica”. Ei sunt cei care „narează” drumul existențial al creației spre sfințirea la care este chemată, sunt „metanarațiunea” iubirii divine sădită în creație. Sunt „rațiunea” care face posibilă „rostirea” existențială, exprimată magistral de psalmistul care zice: „Cerurile spun slava lui Dumnezeu, iar facerea mâinilor Lui o vesteşte tăria" (Ps. 18, 1). Această bucurie a rostirii, se concretizează, însă, mereu, ca multumire/euharistie, ca "darul euharistic de la Cina cuvântului de Taină ${ }^{, 53}$, de la acea „Cină” în care hrana nu mai este doar cea a cuvântului ca nutrient al limbajului comunional, ci cea a „Cuvântului" care a devenit „carne/trup” (In. 1, 14) şi se dă spre mâncare, pentru a ostoi „foamea” creației.

„Foamea" unei ființe, fie ea şi cea eclesială, nu poate fi, aşadar, ostoită decât prin ,pâinea cea de toate zilele”, care prin însuşi faptul că are atributul acesta al sațietăţii îndumnezeitoare, devine „pâinea cea spre ființ ă”, devine hrana care face ca perceperea intelectului eclesial să fie una corectă, chiar dacă ea trebuie trecută prin prisma simțurilor, simțurile fiind cele ale mădularelor acestei ființe, ale fiecărui creştin în parte şi a tuturor întreolaltă.

Numai un astfel de modus vivendi al Bisericii, o poate face pe aceasta să devină orânduitoarea definitivă a destinului omenirii, dar nu al unui destin lipsit de perspectiva hristică, lipsit de demnitate umană, aşa cum sugera Marele Inchizitor, ci al unui destin demn, în care Biserica în integralitatea ei, dar şi prin fiecare mădular în parte să poată să spună: „Nu mai trăiesc eu, ci Hristos trăieşte în mine" (Gal. 2, 20).

Atunci când creştinul afirmă aceasta, o face numai şi numai pentru că are, aşa cum spune dumnezeiescul Pavel, mintea/voũ $\zeta-$-ul

52 John Meyendorff, Teologia Bizantină..., p. 179-180.

${ }^{53}$ Pr. Prof. Ion Buga, op. cit., p. 149. 
lui Hristos: „Noi, insăa, avem minteavoũ̌-ul lui Hristos” (I Cor. 2, 16).

Când vorbesc de mintea cea îndumnezeită a Bisericii, Sf. Părinții o fac mereu din perspectiva hranei pe care Hristos o dăruieşte Bisericii Sale, din perspectiva hranei euharistice. Din aceasta se desprinde faptul că, Biserica trăiește numai şi numai pentru că primeşte hrana cea vie - Euharistia. Or, tocmai această hrănire este pecetluirea inimii Bisericii de către Hristos, care i se adresează Bisericii, spunându-i: „Dă-mi mie (...) inima ta” (Pilde, 23, 26).

Dăruindu-şi inima lui Hristos, Biserica îşi simte mintea şi conştiinţa străfulgerate şi îndumnezeite prin Duhul Sfânt, de către Hristos, devenind toată mintea şi conştiinţa Lui. Ea gândeşte şi conştientizează, astfel, prin mintea Lui. Cincizecimea, care reprezintă "tipătul Duhului Sfânt" în Biserică, se actualizează mereu în cadrele acestei tainice lucrări, prin care fiecare mădular în parte devine prin Euharistie, locaşul prezenței tainice a lui Hristos.

Mintea, îndumnezeită prin hrana Euharistică, se pogoară în inimă, devenind liturgul de pe altarul unei inimi demne, săvârşind ceea ce Părinții Bisericii numesc Liturghia noetică. Această pogorâre a minții în inimă se face nu pentru a zidi un nou şi înfricoşător Turn Babel, ci pentru a liturghisi în Templul euharistic-noetic al omului celui nou, al demnității sale restaurate şi renăscute ca mlădiță altoită în demnitatea viei vieții celei veşnice, Iisus Hristos.

Strigătul umanităţii bicisnice şi lipsite de orice urmă de demnitate, de care vorbea Marele Inchizitor - „Inrobiți-ne, dar astâmpărați-ne foamea!", devine glasul umanității demne, renăscute întru dragostea lui Hristos, devine glasul martirilor care, în timpul pătimirilor lor, îi dăruiau lui Hristos, Celui Care le dăduse spre mâncare trupul Său, trupurile lor, străfulgerate de sfințirea firii, într-o dinamică a creaţiei în care orice urmă de înjosire şi suferință este înghițită de biruinţa definitivă a demnităţii hristice restauratoare şi vindecătoare. 


\section{4. În loc de concluzii, sau ethosul euharistic al Bisericii ca „metanarațiune" îndumnezeitoare}

Atunci când Hristos hrăneşte Biserica Sa cu trupul Său, aceasta devine ea însăşi trupul Său. Ca urmare, El fiind capul ei, ea are mintea/voũo-ul lui. Schimbarea unui anume tip de mentalitate sau invitația la o schimbare de mentalitate, de care vorbea şi J.-Fr. Lyotard, nu poate avea loc decât aici şi acum, în cadrul acestei hrăniri şi ea transcende atât modernitatea, cât şi postmodernitatea, căci Hristos îşi hrăneşte trupul Său într-un continuu „astăzi”: „Cinei Tale celei de Taină, Fiule al lui Dumnezeu, astăzi părtaş mă primeşte...". Dacă se pune problema unei schimbări a unui tip de mentalitate, în sensul unui ,aggiornamento", aceasta nu se poate face decât în şi de către Biserică, prin trecerea de la o existență babilonică la una euharistică.

Turnul Babel cel cumplit este dărâmat, pe locul său zidinduse Templul în care mintea cea îndumnezeită a Bisericii săvârşeşte veşnica Liturghie noetică. Ea se opune mereu comportamentului oedipic şi inchizitorial, căci nefăcându-o, ea riscă să orbească şi să devină, astfel, ochiul nevăzător, incapabil să mai distingă Adevărul.

În această Liturghie noetică, locul Marelui Inchizitor este luat de Marele Arhiereu, Hristos, pe care Biserica îl va urma pentru a primi ,iară şi iară în pace” pâinea cea cerească. Repetiția, acest „iară şi iară în pace", acest memento al liturghisirii euharistic-noetice nu mai devine, în cazul acesta, expresia unei nevroze şi psihoze, ci devine conturul acelui destin în care viitorul este înscris în trecutul deja spus în veşnica rostire euharistică a lui ,astăzi”. Palierul acesta, al „repetiției”, devine, astfel, substratul celuilalt, al „rememorării”, în care Biserica, în anamneza liturgică-euharistică, nu face decât să devină în chip tot mai vizibil, orânduitoarea definitivă a destinului omenirii, a destinului eshatologic al veşnicului „astăzi” euharistic: „Aducându-ne aminte, aşadar, de această poruncă mântuitoare (...) şi de cea de-a doua slăvită iarăşi a Ta venire, ale Tale, dintru ale Tale, Ție îţi aducem de toate şi pentru toate".

1. Aserţiunea filosofului materialist german Feuerbach - „Omul 
este ceea ce mănâncă" - devine, în chip paradoxal, paradigma demnității Bisericii hrănită de Hristos: Ea devine, ceea ce primeşte - trupul Lui. Astfel, ea simte cu Hristos, prin El şi cu El; „simţul” ei este Hristos însuşi, aşa încât, axioma tomistă a simţirii percepută de minte, devine axioma eclesială a minții percepută de simţire, a unei minţi şi a unei simţiri restaurate ontologic în demnitatea Dumnezeu-Omului, Iisus Hristos. Astfel, căutarea, desemnarea şi numirea faptelor ascunse pe care le imaginăm la originea răului de care suferim, nu mai rămâne la stadiul în care nu vom face altceva decât să perpetuăm crima, să o comitem, în loc să-i punem capăt. Eşecul unei astfel de „metanarațiuni” care doreşte a rescrie un anume tip de mentalitate, este transformat în izbânda vindecătoare a ființei celei noi, restaurată ontologic în demnitatea hristică. Orbirea oedipică şi înrobirea inchizitorială, transformate în vederea slavei dumnezeieşti şi-n libertatea fiilor lui Dumnezeu, devin acel „Grund" sau ,principiu originar" al „re-scrierii”, respectiv al „rememorării” în care se cere mereu ceva nou. De fapt, Biserica cere mereu ceva nou: „Dă-ne nouă să ne împărtăşim cu tine în alt mod...”. Aceasta este, de fapt, adevărata „rescriere" a veacurilor.

De aceea, imperativul ontologic al Bisericii este acela al primirii perpetue a hranei celei demne, a hranei euharistice, pentru ca Euharistia să-i devină, astfel, hrana cea de toate zilele, să-i devină cu adevărat spre ființă şi s-o călăuzească pe drumul ei între dinamica creației şi sfințirea firii, să devină „metanarațiunea” îndumnezeitoare a ei. 


\section{Bibliografie}

\section{A. Izvoare}

1. Sf. Maxim Mărturisitorul, Răspunsuri către Talasie, în Filocalia sfintelor nevointe ale desăvârşirii sau culegere din scrierile Sfinților Părinți care artă cum se poate omul curăți, lumina şi desăvârşi, vol. 3, traducere, introducere și note de Preotul Profesor Dr. Dumitru Stăniloae, Ediția a III-a, Seria „Scrieri Traduceri - 12 de Pr. Prof. Dr. Dumitru Stăniloae" Bucureşti, EIBMBOR, 2009 (Ediţia a II-a, Bucureşti, Editura Harisma, 1994).

2. Sf. Maxim Mărturisitorul, Ambigua. Tîlcuiri ale unor locuri cu multe şi adinci ințelesuri din sfinți Dionisie Areopagitul şi Grigorie Teologul, traducere din grecește, introducere şi note de Pr. Prof. Dumitru Stăniloae, în colecția „Părinți și Scriitori Bisericeşti”, vol. 80, Bucureşti, EIBMBOR, 1983.

3. Sf. Vasile cel Mare, Omilii la Hexaemeron, traducere şi note de Pr.

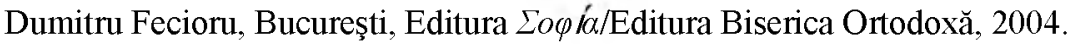

\section{B. Manuale}

4. Altaner, Berthold, Patrologie, Freiburg im Breisgau, Herder \& CO. G.M.B.H. Verlagsbuchhandlung, 1938.

5. Voicu, Arhid. Prof. Dr. Constantin, Patrologie, vol. I, București, Editura Basilica a Patriarhiei Române, 2009.

\section{Literatură secundară}

6. Boboc, Al., Constantin Rădulescu-Motru în gândirea contemporană. Postfață la vol. Constantin Rădulescu-Motru, Psihologia poporului român şi alte studii de psihologie socială, ediție îngrijită de Alexandru Boboc, Colecția de studii şi eseuri, Bucureşti, Paideia, 1998.

7. Buga, Ion, Testament Gutenberg, București, Editura Sf. Gheorghe-Vechi, 2015 .

8. Lyotard, J.-Fr., A rescrie modernitatea, în: Viata Românească -Revistă a Uniunii Scriitorilor, anul LXXXVII, iunie-iulie, 1992, nr. 6-7, p. 122-127, traducere de Smaranda Vultur, după originalul francez Réecrire la modernité din vol. L'inhumain. Causeries sur le temps, Paris, Edition Galilée, 1988.

9. Meyendorff, John, Teologia Bizantină. Teme istorice şi tendinte doctrinare, traducere din limba engleză de Preot conf. dr. Alexandru I. Stan, seria „Teologi ortodocși străini”, București, EIBMBOR, 1996. 
10.Rădulescu-Motru, Constantin, Personalismul energetic, București, Casa Şcoalelor, 1927.

11.Rădulescu-Motru, Constantin, Psihologia poporului român şi alte studii de psihologie socială, ediție îngrijită de Alexandru Boboc, Colecția de studii şi eseuri, București, Paideia, 1998.

12.Vultur, I., O versiune a postomdernității, în: Viața Românească - Revistă a Uniunii Scriitorilor, anul LXXXVII, iunie-iulie, nr. 6-7, 1992, p. 121.

13.***, Marele Inchizitor. Dostoievski - lecturi teologice, traducere din limba rusă de Leonte Ivanov, colecția „Plural M”, Iași, Polirom, 1997.

14.***, Notă introductivă la vol. Constantin Rădulescu-Motru, Psihologia poporului român şi alte studii de psihologie socială, ediție îngrijită de Alexandru Boboc, Colecția de studii şi eseuri, Bucureşti, Paideia, 1998.

\section{Surse web}

15. Art. Jean-François Lyotard, la adresa:

http://en.wikipedia.org/wiki/Jean-Fran\%C3\%A7ois_Lyotard (Standul accesării: 25.04.2015).

16. Art. Jürgen Habermas, la adresa:

http://en.wikipedia.org/wiki/J\%C3\%BCrgen_Habermas

(Standul accesării: 25.04.2015).

17. Art. Constantin Rădulescu-Motru, la adresa:

http://ro.wikipedia.org/wiki/Constantin_R\%C4\%83dulescu-Motru (Standul accesării: 25.04. 2015).

18. Quaestiones disputatae de veritate, q. 2, art. 3, arg. 19, la adresa: http://www.hispanoteca.eu/Lexikon\%20der\%20Linguistik/e/EMPIRISMUS $\% 2$ 0\%20\%20Empirismo.htm (Standul accesării: 25.04.2015). 